\title{
Phytogeography of seaweeds of the Azores*
}

\author{
W. F. Prud'homme van Reine** \\ Rijksherbarium; P.O. Box 9514, 2300 RA Leiden, The Netherlands
}

\begin{abstract}
Atlantic archipelago of the Azores (114 Rhodophyceae, 41 Phaeophyceae and 34 Chlorophyceae). Ten of these have been described as endemic algae. The taxonomic status of these "endemics" is far from clear, however. Studies on the relatedness of this seaweed flora to seaweed floras of surrounding areas using clustering methods indicate its intermediary position between the seaweed floras of the subtropical Macaronesian Islands (Canaries, Madeira and Salvages) on the one side and those of the warm temperate Eurafrican coasts on the other side. The geographic position of the Azores is NW of the other Macaronesian Archipelagos and thus nearer to the American coast. The Gulf stream may easily transport seaweeds from the Carribean to the Azores. Nevertheless, the number of species of these islands in common with the American Atlantic coast is much lower than with, for example, the W. Mediterranean. Of one group of seaweeds, viz. algae with a strictly warm temperate distribution, not a single species occurs likewise on American coasts. This absence is probably explicable because of the narrow temperature range for survival of these seaweeds. Temperatures of surface waters around the Azores during pleistocene glaciations were not much lower than they are at present. Nevertheless, it can be supposed that a number of seaweeds now occurring in the Azores have become extinct during the last glaciation.
\end{abstract}

\section{INTRODUCTION}

In his paper dealing with the marine flora of Atlantic islands, Feldmann (1946) characterized the seaweed flora of the Azores as boreal, poor in species, and without any of the species that occur on the Atlantic coasts of $N$. America but that are absent from the E. Atlantic. According to Feldmann (l.c.), the Azores form part of the Lusitano-African region, like the other Macaronesian islands (except the Cape Verde Islands). In recent phytogeographic studies, the position of the Azores is rarely discussed, but they have been incorporated in the list of benthic marine algae of the North Atlantic Ocean (South \& Tittley, 1986), and Van den Hoek (1984) included the Azorean archipelago in the Warm temperate NE Atlantic Region.

The purpose of the present study is to explore further the biogeographic position of the Azores using new floristic data in addition to older ones. The new floristic data were collected during the CANAP-V-Expedition (1981) of the Netherlands Council of Sea Research (NRZ).

\footnotetext{
- Paper presented at the XIV International Botanical Congress (Berlin, 24 July-1 August, 1987), Symposium 6-15, "Biogeography of marine benthic algae".

* CANCAP-project. Contributions to the zoology, botany and paleontology of the Canarian-Cape Verdean region of the North Atlantic Ocean. No. 67.
} 


\section{MATERIALS AND METHODS}

Lists of species of seaweeds recorded from the Azores (Schmidt, 1931; Pryor, 1967; Ardré et al., 1973, 1974, and unpublished records from CANCAP-V) have been compared with lists prepared for a number of selected geographic areas (cf. Fig. 1, Tables 1 and 2, and Prud'homme van Reine \& Van den Hoek, 1988).

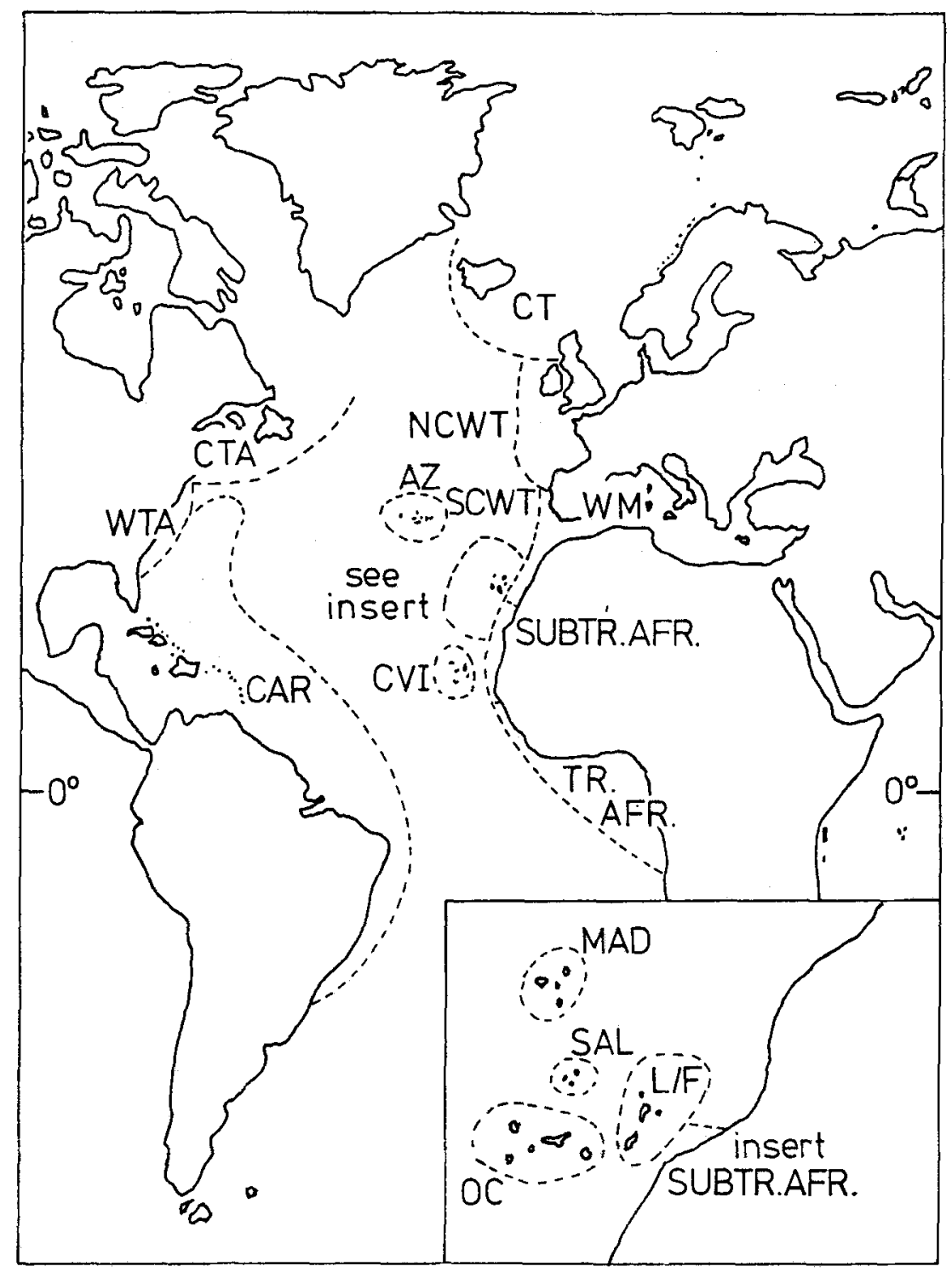

Fig. 1. The areas taken for the comparison of their seaweed flora with that of the Azores. For abbreviations denoting geographic areas see Table 1 
The designation "assembled seaweed flora" is used for the total of the floras of red, brown, and green seaweeds altogether. However, in this paper this will generally be shortened as a "given area's (seaweed) flora". (for instance, the Azorean flora). If, however, the designation "seaweed floras of a given area" is used, it refers to the separate floras of red, brown, and green seaweeds.

Table 1. List of abbreviations denoting geographic areas (coasts). For delimination of these areas see Fig. 1 and Prud'homme van Reine \& Van den Hoek (1988)

\begin{tabular}{|ll|}
\hline AZ & Azores \\
CAR & Caribbean \\
CT & Europe: Scotland, Norway and the countries around North Sea and Baltic \\
CTA & NE America, north of Cape Cod \\
CVI & Cape Verde Islands \\
L/F & Lanzarote, Fuerteventura and surrounding islets \\
MAD & Madeira Archipelago \\
Macar.s.s. & Macaronesia sensu stricto (L/F, MAD, OC and SAL) \\
NCWT & NE Spain, Atlantic France, S, SW and NW England, Wales, Ireland \\
OC & Canary Islands except L/F \\
SAL & Salvage Islands \\
SCWT & Morocco (excl. former Spanish Sahara), Atlantic SW Spain, Portugal \\
Subtr. Afr. & NW Senegal (North of Gambia), Mauretania, former Spanish Sahara \\
Tr. Afr. & From Gambia to the Congo River \\
WM & Western Mediterranean (see text) \\
WTA & NE America between Cape Canaveral and Cape Cod \\
\hline
\end{tabular}

In the present study, the very broad warm temperate, NE Atlantic Region (Van den Hoek, 1984) has been divided into three subregions in the same way as described by Prud'homme van Reine \& Van den Hoek (l.c.; see also my present Table 3). The Azorean seaweed flora can be expected potentially to encompass species of the following climatic distribution groups (or distribution types): tropical-to-southern cooler warm temperate (SCWT), tropical-to-northern cooler warm temperate (NCWT), tropical-to-cold temperate, tropical-to-arctic, subtropical-to-SCWT, subtropical-to-NCWT, subtropical-to-cold temperate (here including tropical-to-arctic), SCWT proper, SCWT-to-NCWT and SCWT-to-cold temperate (here including SCWT-to-arctic) (cf. also Table 4). For discussion about the delimitation of the areas, see Prud'homme van Reine \& Van den Hoek (1988); for the concept "climatic distribution group" see Van den Hoek $(1979,1982 \mathrm{~b}$, 1982c).

To analyse the data the same methods have been used as described in Prud'homme van Reine \& Van den Hoek (1988).

\section{RESULTS}

189 of the 1505 species of seaweed included in the data matrix (921 Rhodophytes, 329 Phaeophytes and 255 Chlorophytes) have been recorded from the Azores. For numbers of species shared with other areas, see Table 5.

Results of Group clustering of, respectively, the Rhodophycean, Phaeophycean, Chlorophycean, and assembled (= total) seaweed floras using the Preston dissimilarity 
Table 2. References consulted to list the species compositions of seaweed floras in the various regions. For abbreviations denoting geographic areas (first column) see Table 1

\begin{tabular}{|c|c|}
\hline CAR & Collins \& Hervey (1917), Van den Ḣoek (1982a), Taylor (1960), Wynne (1986) \\
\hline CVI & $\begin{array}{l}\text { Askenasy (1886), Bailey \& Harvey (1862), Feldmann (1935), John et al. (1979), } \\
\text { Lawson \& Price (1969), Lemoine (1964), Price et al. (1978, 1986), Prud'homme van } \\
\text { Reine (1984), Prud'homme van Reine et al. (1984), Reinbold (1908) }\end{array}$ \\
\hline Tr. Afr. & $\begin{array}{l}\text { John et al. (1979), Lawson \& John (1982), Lawson \& Price (1969), Price et al. (1978, } \\
\text { 1986) }\end{array}$ \\
\hline Subtr. Afr. & $\begin{array}{l}\text { Bodard \& Mollion (1974), Dangeard (1952), Hariot (1911), John et al. (1979), } \\
\text { Lawson \& John (1977), Lawson \& Price (1969), Naegelé (1960), Price et al. (1978, } \\
\text { 1986), Primo (1953), Seoane-Camba (1960), Sourie (1954a, 1954b) }\end{array}$ \\
\hline OC & $\begin{array}{l}\text { Afonso-Carrillo (1984), Afonso-Carrillo \& Gil-Rodríguez (1982), Afonso-Carrillo et } \\
\text { al. (1984, 1985), Audiffred (1985), Gil-Rodríguez \& Afonso-Carrillo (1980, 1982), } \\
\text { Gil-Rodríguez et al. (1984, 1985), Haroun-Tabraue et al. (1984), Prud'homme van } \\
\text { Reine et al. (1984) }\end{array}$ \\
\hline $\mathrm{L} / \mathrm{F}$ & $\begin{array}{l}\text { Afonso-Carrillo (1984), Afonso-Carrillo \& Gil-Rodríguez (1980), Afonso-Carrillo et } \\
\text { al. }(1984,1985) \text {, Gil-Rodríguez \& Afonso-Carrillo }(1980,1982) \text {, Gil-Rodríguez et al. } \\
(1984,1985) \text {, Prud'homme van Reine et al. (1984) }\end{array}$ \\
\hline SAL & Audiffred \& Weisscher (1984) \\
\hline MAD & $\begin{array}{l}\text { Audiffred \& Prud'homme van Reine (1985), Cabioch (1974), Levring (1974), } \\
\text { Pedersen (1983), Prud'homme van Reine et al. (1984) }\end{array}$ \\
\hline $\mathrm{AZ}$ & André et al. $(1973,1974)$, Schmidt (1931), South \& Tittley (1986) \\
\hline WM & $\begin{array}{l}\text { Boudouresque \& Perret (1977), Boudouresque et al. (1984), Codomier (1971), } \\
\text { Coppejans (1977, 1979, 1983), Coppejans \& Boudouresque (1983), Feldmann- } \\
\text { Mazoyer (1940), Funk (1927, 1955), Fumari \& Scammacca (1973), Gallardo et al. } \\
\text { (1985), Giaccone (1969), Hamel (1924-31, 1924-36, 1931-39), Hamel \& Lemoine } \\
\text { (1952), Van den Hoek (1963), Koster (1941), Lauret (1968, 1970), Meñez \& } \\
\text { Mathieson (1981), Ollivier (1929), Preda (1908), Sauvageau (1912), Schotter (1968), } \\
\text { Verlaque (1981), Verlaque \& Boudouresque (1981), Verlaque \& Tine (1981), Verla- } \\
\text { que et al. (1977) }\end{array}$ \\
\hline NCWT & South \& Tittley (1986) \\
\hline SCWT & $\begin{array}{l}\text { Bornet (1892), Dangeard (1949), Debray (1897), Gayral (1958, 1960, 1961), Hamel } \\
(1924-31,1924-36,1931-1939) \text {, Hamel \& Lemoine (1952), South \& Tittley (1986) }\end{array}$ \\
\hline CT & South \& Tittley (1986) \\
\hline CTA & Van den Hoek (1982a), South \& Tittley (1986), Taylor (1957) \\
\hline WTA & Van den Hoek (1982a), South \& Tittley (1986), Taylor (1957, 1 \\
\hline General: & $\begin{array}{l}\text { Denizot (1968), Falkenberg (1901), Kuckuck (1964), Prud'homme van Reine (1982), } \\
\text { Silva (1960) }\end{array}$ \\
\hline
\end{tabular}

Table 3. Delimitation of regions and subregions along the NE Atlantic coasts

\begin{tabular}{|c|c|c|c|}
\hline \multirow{2}{*}{$\begin{array}{l}\text { Latitudinal boundaries } \\
\text { between (sub)regions }\end{array}$} & \multicolumn{2}{|c|}{ Boundary on or halfway between } & \multirow{2}{*}{$\begin{array}{r}\text { Boundary } \\
\text { yearly isoth }\end{array}$} \\
\hline & $\begin{array}{c}\text { winter } \\
\text { isotherm }\end{array}$ & $\begin{array}{l}\text { summer } \\
\text { isotherm }\end{array}$ & \\
\hline $\begin{array}{l}\text { Tropical E Atlantic region and } \\
\text { subtropical subregion }\end{array}$ & $20^{\circ} \mathrm{C}$ & $25^{\circ} \mathrm{C}$ & $22.5^{\circ} \mathrm{C}$ \\
\hline $\begin{array}{l}\text { Subtropical subregion and southern } \\
\text { cooler warm temperate subregion }\end{array}$ & $16.5^{\circ} \mathrm{C}$ & $21.5^{\circ} \mathrm{C}$ & $18.5^{\circ} \mathrm{C}$ \\
\hline $\begin{array}{l}\text { Southern cooler warm temperate sub- } \\
\text { region and northern cooler warm } \\
\text { temperate subregion }\end{array}$ & $12.5^{\circ} \mathrm{C}$ & $18.5^{\circ} \mathrm{C}$ & $15.5^{\circ} \mathrm{C}$ \\
\hline $\begin{array}{l}\text { Northern cooler warm temperate } \\
\text { subregion and cold temperate region }\end{array}$ & $10^{\circ} \mathrm{C}$ & $15^{\circ} \mathrm{C}$ & $12.5^{\circ} \mathrm{C}$ \\
\hline
\end{tabular}


Table 4. List of abbreviations denoting climatic distribution groups. For delimitation see Van den Hoek (1984) and Table 3

\begin{tabular}{|ll|}
\hline CT & Cold Temperate \\
NCWT & Northern Cooler Warm Temperate \\
SCWT & Southern Cooler Warm Temperate \\
Subtr. & Subtropical \\
Tr. & Tropical \\
WT & Warm Temperate \\
\hline
\end{tabular}

Table 5. Azorean seaweeds shared with other areas. For abbreviations denoting geographic areas see Table 1

\begin{tabular}{|c|c|c|c|c|c|}
\hline \multicolumn{6}{|c|}{ Number of species of seaweeds } \\
\hline & Red & Brown & Green & Sum total & \\
\hline $\begin{array}{l}\text { Total numbers in the } \\
\text { Azores }\end{array}$ & 114 & 41 & 34 & 189 & \\
\hline $\begin{array}{l}\text { N. of these in the } \\
\text { Atlantic, restricted to } \\
\text { the Azores }\end{array}$ & 8 & 0 & 2 & 10 & \\
\hline N. of endemics & 4 & - & 2 & 6 & \\
\hline $\begin{array}{l}\text { Species also recorded } \\
\text { from outside the areas } \\
\text { studied }\end{array}$ & 4 & - & 0 & 4 & $\begin{array}{l}\text { Total number of sea- } \\
\text { weeds in the seaweed } \\
\text { floras of the separate } \\
\text { areas: }\end{array}$ \\
\hline SCWT & 92 & 33 & 25 & 150 & 560 \\
\hline NCWT & 82 & 31 & 23 & 136 & 754 \\
\hline WM & 93 & 32 & 27 & 152 & 828 \\
\hline Subtr. Afr. & 51 & 18 & 15 & 84 & 296 \\
\hline Tr. Afr. & 39 & 10 & 19 & 68 & 301 \\
\hline CVI & 34 & 17 & 11 & 62 & 223 \\
\hline OC & 76 & 29 & 26 & 131 & 402 \\
\hline $\mathrm{L} / \mathrm{F}$ & 52 & 27 & 17 & 96 & 244 \\
\hline SAL & 40 & 22 & 17 & 79 & 193 \\
\hline MAD & 66 & 24 & 23 & 113 & 292 \\
\hline
\end{tabular}

coefficient displays different clusters of the Azores seaweed floras with either the seaweed floras of the warm temperate Eurafrican coasts, or with those of Macaronesia sensu stricto (cf. Table 1), or with both clusters together (thus excluding only the Cape Verde Islands, Tropical Africa and Subtropical Africa). In Figure 2 the result of clustering assembled seaweed floras is given.

The Cumulative Minimal Spanning Subtrees also showed differences in the way the Azorean seaweed flora could be linked to other seaweed floras. In Figure 3 the result for the green seaweeds is given: in Figure 4 the result for the assembled seaweed floras. 


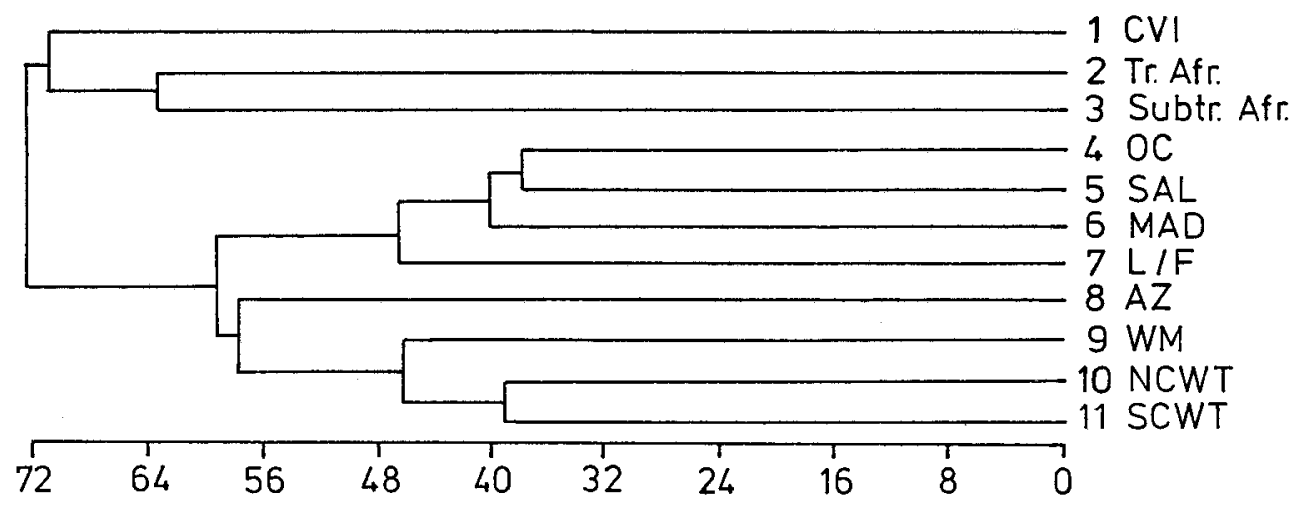

Fig. 2. Dendrogram of a Group cluster analysis of the assembled seaweed floras compared according to Preston's dissimilarity coefficient. For abbreviations denoting geographic areas see Table 1

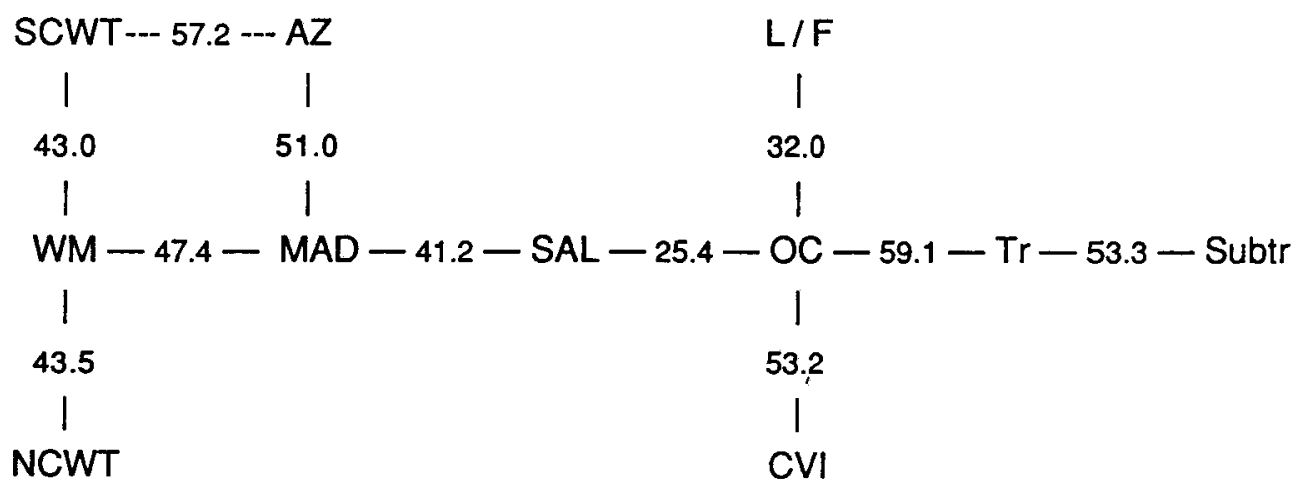

Fig. 3. Cumulative Minimal Spanning Subtree of the green seaweed floras when compared according to Preston's dissimilarity coefficient. For abbreviations denoting geographic areas see Table 1. Dissimilarity is given as percentage. Solid lines represent links of lowest dissimilarity. Broken lines represent another possible link, to which is added its dissimilarity value

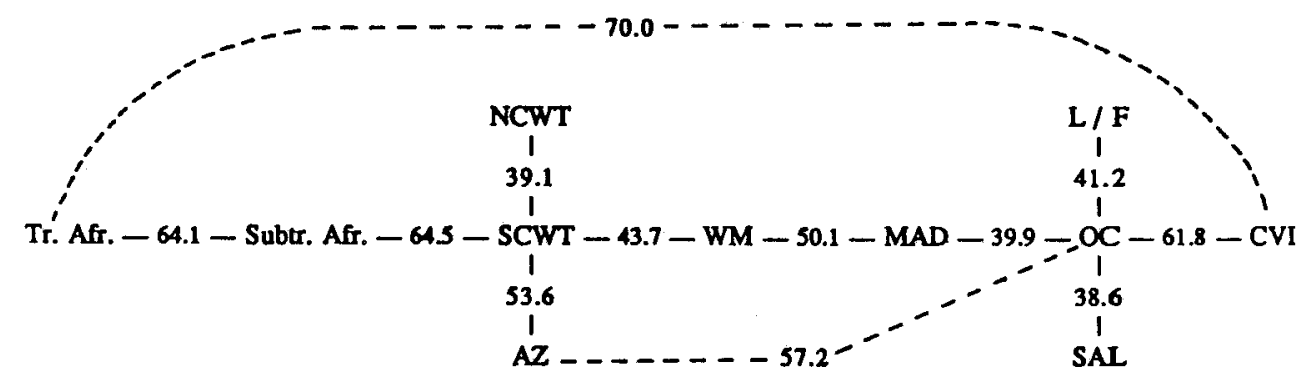

Fig. 4. Cumulative Minimal Spanning Subtree of the assembled seaweed floras when compared according to Preston's dissimilarity coefficient. For abbreviations denoting geographic areas see Table 1. Dissimilarity is given as percentage. Solid lines represent links of lowest dissimilarity. Broken lines represent other possible links, to which their dissimilarity values are added 


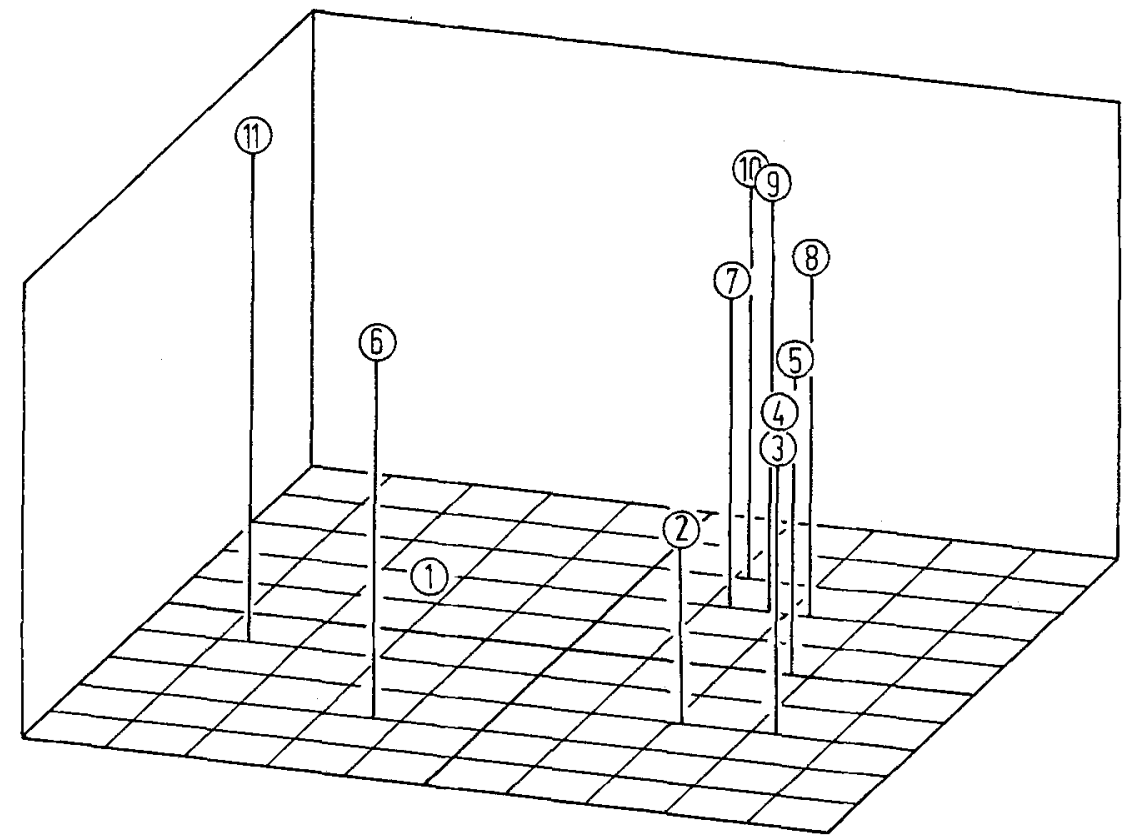

Fig. 5. Three dimensional visualization of (dis-)similarities between brown seaweed floras compared according to Preston's dissimilarity coefficient. The first principal axis (X-axis) explains 27 percent of the variation, the (Y) 21 and the third (Z) 11 percent. The meaning of the numbers denoting the geographic areas is as follows: $1=$ Cape Verde Islands; 2 = Azores; $3=$ NE Spain, Atlantic France, S., SW and NW England, Wales, Ireland; $4=$ Morocco (excl. former Spanish Sahara), Atlantic SW Spain, Portugal; $5=$ Western Mediterranean; $6=$ Subtr. Afr.: NW Senegal (North of Gambia), Mauretania, former Spanish Sahara; $7=$ Canary Islands except Lanzarote, Fuerteventura and surrounding islets; $8=$ Madeira Archipelago; $9=$ Lanzarote, Fuerteventura and surrounding islets; $10=$ Salvage Islands; $11=$ Tr. Afr: From Gambia to the Congo River

When a three-dimensional system is used to elucidate the (dis-)similarities of the seaweed floras of the areas, only ca $60 \%$ of the (dis-)similarities in the $\mathrm{n}$-dimensional space can be visualized. The intermediary position of the seaweed flora of the Azores can be best figured by the results for the brown seaweeds (Fig. 5). For the assembled seaweed floras, see Figure 5 in Prud'homme van Reine \& Van den Hoek (1988).

In Figure 6 and Table 6 the results of the comparison of the species of the Azorean seaweed flora shared with Atlantic America on the one side and with Atlantic Eurafrica on the other side are summarized. The Azorean species shared with Macaronesia s.s. and with the western part of the Mediterranean are also indicated. One should realize that the total number of species in each climatic distribution group is only given for the Azorean flora. For other floras, only those species of each distribution type are given that are shared with this Azorean flora. Thus, the total numbers of each climatic distribution group in each flora may be larger than indicated here. For the acutal numbers of species of geographic areas in the NE Atlantic Ocean see Table 7, Figure 7, and Table 5, last column. The numbers of species shared with the Azorean seaweed flora as well as the numbers of endemics are also given. 
W. F. Prud'homme van Reine

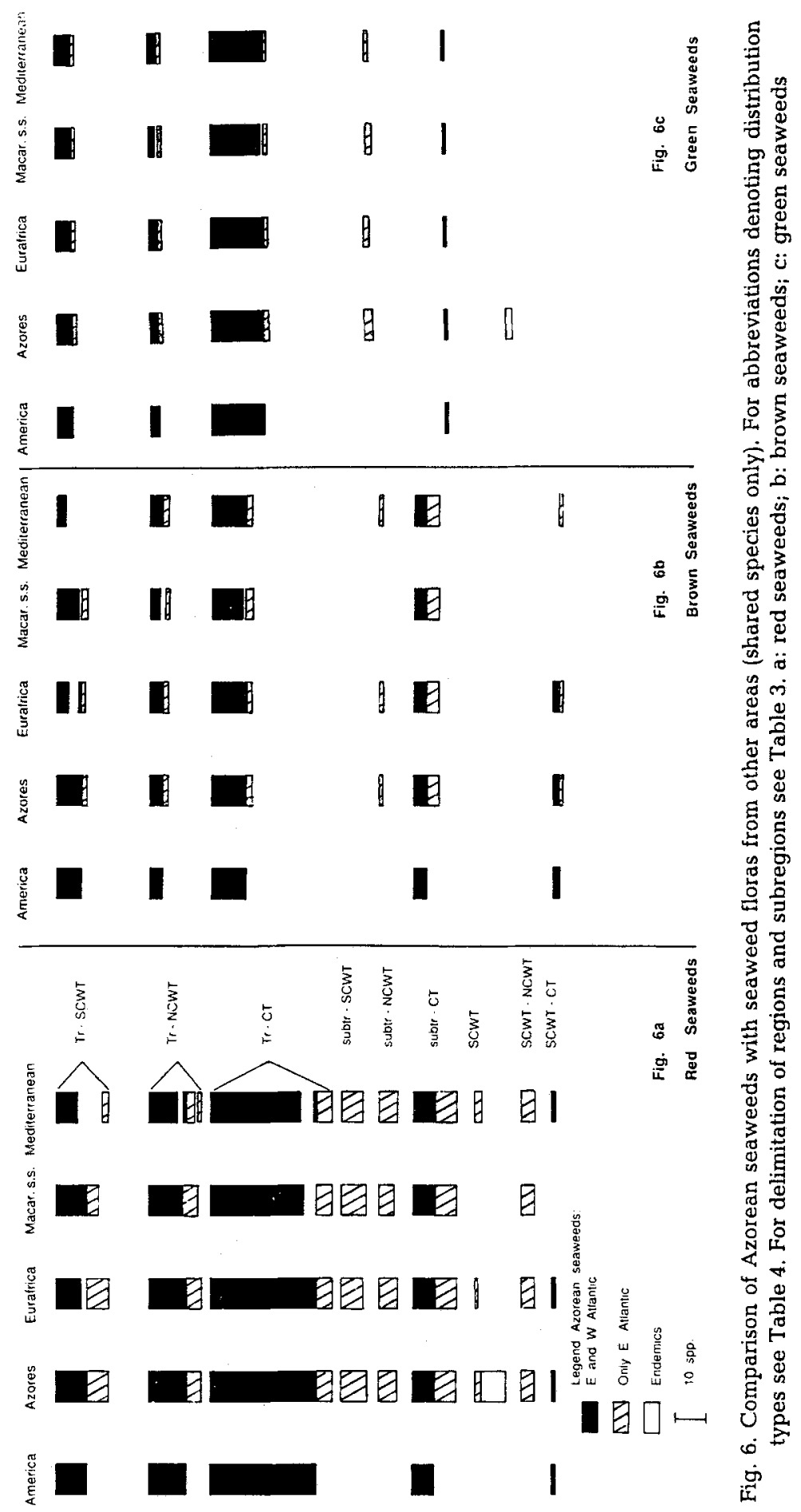


Table 6. Comparison of Azorean seaweed floras with other seaweed floras (numbers of shared species only). For abbreviations denoting distribution types see Table 4. For abbreviations denoting geographic areas see Table 1. "Eurafrican coasts" stands for the warm temperate W European and NW African Atlantic coasts

\begin{tabular}{|c|c|c|c|c|c|}
\hline $\begin{array}{l}\text { Distribution } \\
\text { types }\end{array}$ & $\begin{array}{l}\text { American } \\
\text { coasts }\end{array}$ & $\mathrm{AZ}$ & Macar.s.s. & $\begin{array}{c}\text { Eurafrican } \\
\text { coasts }\end{array}$ & WM \\
\hline \multicolumn{6}{|c|}{ Red seaweeds } \\
\hline Tr-WT & 22 & 32 & 27 & 30 & 23 \\
\hline $\mathrm{Tr}-\mathrm{CT}$ & 34 & 39 & 35 & 39 & 37 \\
\hline WT & 0 & 28 & 13 & 18 & 19 \\
\hline WT-CT & 8 & 15 & 14 & 15 & 14 \\
\hline Total & 64 & 114 & 89 & 102 & 93 \\
\hline \multicolumn{6}{|c|}{ Brown seaweeds } \\
\hline $\operatorname{Tr}-\mathrm{WT}$ & 12 & 16 & 13 & 12 & 9 \\
\hline $\mathrm{Tr}-\mathrm{CT}$ & 11 & 13 & 12 & 13 & 13 \\
\hline WT & 0 & 1 & 0 & 1 & 1 \\
\hline WT-CT & 6 & 11 & 8 & 11 & 9 \\
\hline Total & 29 & 41 & 33 & 37 & 32 \\
\hline \multicolumn{6}{|c|}{ Green seaweeds } \\
\hline Tr-WT & 8 & 10 & 9 & 10 & 7 \\
\hline Tr-CT & 17 & 18 & 17 & 18 & 18 \\
\hline WT & 0 & 5 & 2 & 2 & 1 \\
\hline WT-CT & 1 & 1 & 1 & 1 & 1 \\
\hline Total & 26 & 34 & 29 & 31 & 27 \\
\hline Sum Total & 119 & 189 & 151 & 170 & 152 \\
\hline
\end{tabular}

\section{DISCUSSION}

In this discussion, the "relatedness" between floras is meant as either the reciprocal of the dissimilarity (Figs 2-5) or the number of species shared (Fig. 6, Tables 5 and 6); thus roughly the floristic similarity between floras on the species level.

In all clustering exercises (Figs 2-5), the seaweed floras of the archipelagos of Macaronesia s.s. form a distinct cluster, and the floras of the cooler warm temperate Eurafrican coasts and the W Mediterranean a second distinct cluster. The floras of the Azores and the Cape Verde Islands as well as those of tropical and subtropical Africa are only distantly related to these two larger clusters.

In 8 of the total of 20 different graphs representing the inter-flora relationships based on the Preston-dissimilarity coefficients (Phaeophyceae, Rhodophyceae, Chlorophyceae, assembled [ $=$ total] flores; each processed with single-linkage, Group, Ward, minimal spanning tree, and a three-dimensional graph) the Azores seaweed floras are clustered as a separate unit with the clusters of both Macaronesia s.s. and the warmtemperate Eurafrican coasts (subtropical Africa excluded). In the other graphs the Azorean seaweed floras are either primarily clustered with those of Macaronesia s.s. and later with those of the Eurafrican coasts or primarily with Eurafrica and secundarily with Macaronesia s.s. Only four of these graphs are presented here (cf. Figs 2-5). 


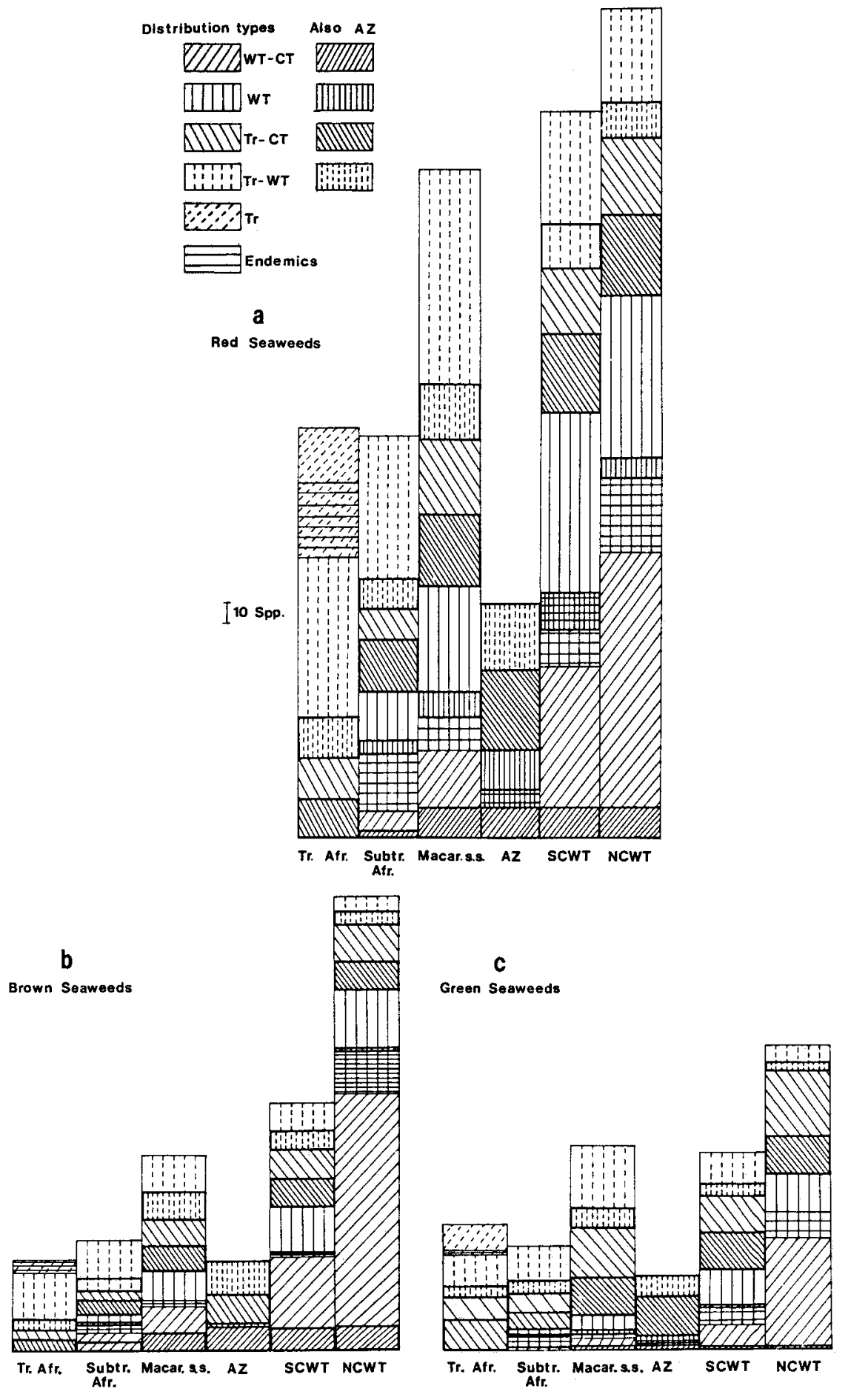


In Figure 2 the assembled seaweed flora of the Azores occupies a separate and individual position, quite distantly related to floras of the warm temperate Eurafrican coasts (excluding the very dissimilar seaweed flora of subtropical Africa, however). The three Eurafrican warm temperate areas are mutually more closely related and a similarly close relatedness can be deduced for the Macaronesian islands sensu stricto. Minimal Spanning Subtrees may also show this close relationship to Eurafrican warm temperate areas (Fig. 4) while in other seaweed groups (Fig. 3) a closer relatedness to Macaronesian islands (s.s.) can be observed. The two larger clusters together with the seaweed flora of the Azores would agree with the Lusitano-African region as proposed by Feldmann (1946).

Figures 6 and 7 , and Tables 6 and 7 give information about the nature of this individual and intermediate position of the Azorean seaweed flora. It is striking that all Azorean seaweeds that have been recorded from the Atlantic coasts of $\mathrm{N}$ America can also be found in the E Atlantic. Feldmann (1946) also perceived this. Thus the situation for the seaweed flora of the Azores is different from that of the Cape Verde Islands. In the latter flora several of these "American" species occur (Prud'homme van Reine \& Van den Hoek, 1988), although both geographic position and the direction of ocean currents suggest relatively easy transport routes for seaweeds from tropical America to the Azores and difficult routes to the Cape Verde Islands.

The prevailing ocean current in the Azores is the N Atlantic Current, the oceanic continuation of the Gulf Stream. Seaweeds that have the ability to survive a several months-long journey may have been dispersed from the $\mathrm{N}$ American coasts to the Azores. For E Atlantic and Macaronesian seaweeds the direction of the surface ocean currents is opposite to the direction of the proposed transport. Nevertheless for all species restricted to the E Atlantic and also occurring at the Azores, transport from the Eurafrican coast or from Macaronesian islands must be supposed. There is no reason to suppose ocean currents to have changed their direction during the time the Azores exist (Sarnthein et al., 1982).

\section{Endemics}

The relative number of strictly warm temperate seaweeds in the Azorean floras is low as compared to the numbers in Macaronesia s.s. and those on Eurafrican temperate coasts (Table 7). The number of endemics, however, is not very different from that in other areas except the W Mediterranean, the latter being an area with high endemism.

Some of the Azorean endemics recorded by Feldmann (1946) have since been recorded from other areas. In some cases, species recorded as Azorean endemics for the Atlantic Ocean have also been recorded from areas outside the Atlantic. In Table 5 these two groups have been separated; in the Tables 7 and 8 the broad definition of endemics is used. Feldmann (1946) listed 9 strict endemics ( 4 red algae and 5 green algae; cf. my

Fig. 7. Numbers of species and the different distribution types composing the seaweed floras of six geographic areas in the NE Atlantic Ocean. For abbreviations denoting geographic areas (horizontal axis) see Table 1. The vertical axis denotes the numbers of species (see small bar in Fig. 7a). For abbreviations denoting distribution types see Table 4 . The numbers of species shared with the Azores and the numbers of endemics of each geographic area are also indicated. a: red seaweeds; $b$ : brown seaweeds; c: green seaweeds 


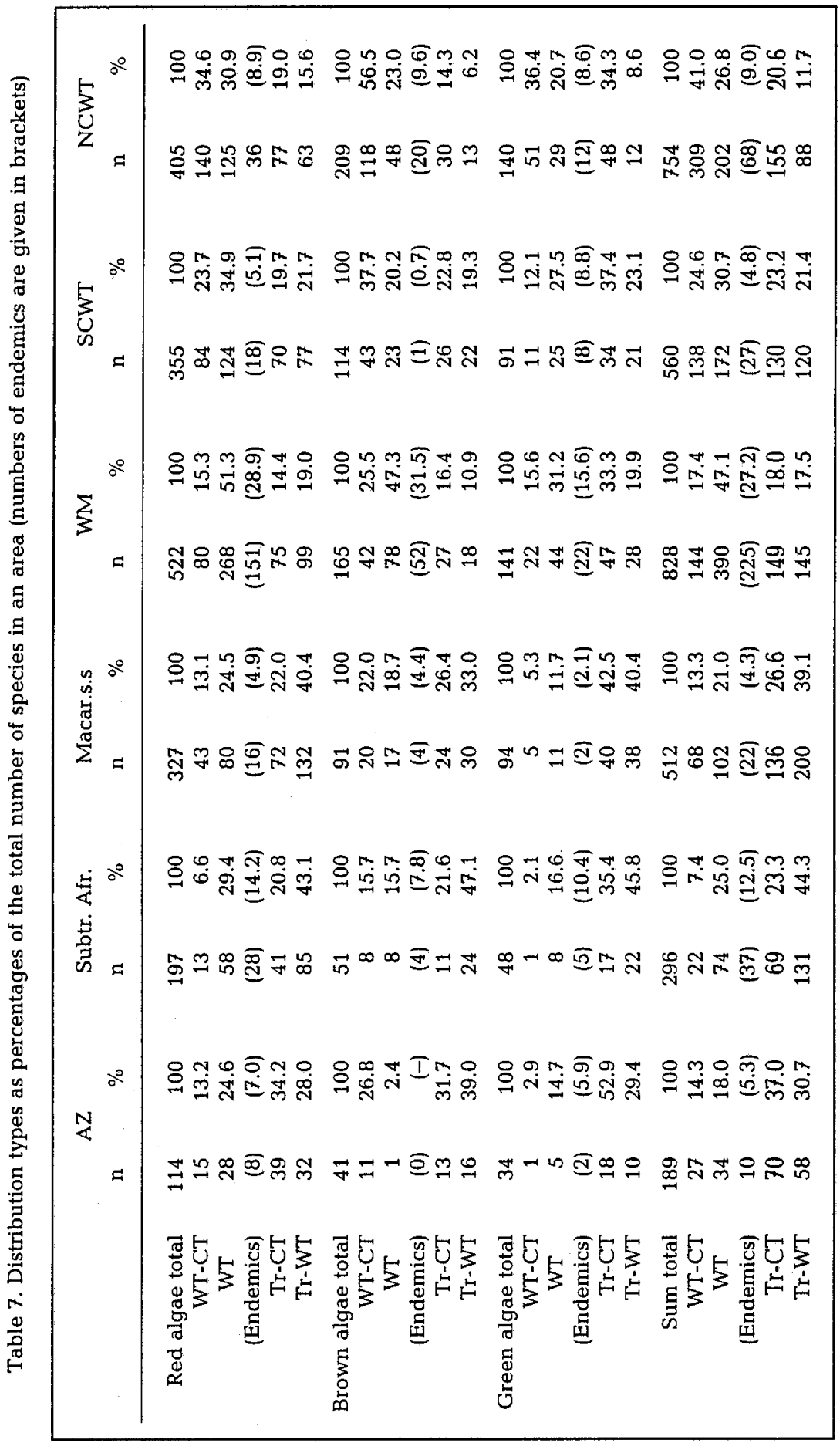


Table 8. Supposed endemic seaweeds of the Azores. $\times=$ strictly endemic $;+=$ relatively endemic, in the Atlantic restricted to the Azores, but also occurring in other oceans; - = not endemic, but recorded as such by Feldmann

\begin{tabular}{|c|c|c|c|}
\hline Species & $\begin{array}{l}\text { In Feldmann } \\
\qquad(1946)\end{array}$ & Remarks & $\begin{array}{l}\text { Found outside } \\
\text { the Azores }\end{array}$ \\
\hline \multicolumn{4}{|l|}{ Red seaweeds } \\
\hline + Liagora divaricata Tseng & no & $\begin{array}{l}\text { det. I. A. } \\
\text { Abbott }\end{array}$ & Pacific Ocean \\
\hline $\begin{array}{l}\times \text { Lithophyllum azorum } \\
\text { Lemoine }\end{array}$ & yes & & \\
\hline $\begin{array}{l}\times \text { Lithophylum bipartitum } \\
\text { Lemoine }\end{array}$ & yes & & \\
\hline $\begin{array}{l}\times \text { Polysiphonia azorica } \\
\text { Schmidt }\end{array}$ & yes & & \\
\hline $\begin{array}{l}\times \text { Polysiphonia hochstetteriana } \\
\text { Schmidt }\end{array}$ & yes & & \\
\hline + Schizymenia obovata J. Ag. & no & doubted by Schmidt (1931) & S. Africa \\
\hline $\begin{array}{l}\text { + Schizymenia undulata J. Ag. } \\
\text { = Grateloupia longifolia } \\
\text { Kylin } 1938\end{array}$ & no & doubted by Schmidt (1931) & S. Africa \\
\hline $\begin{array}{l}\text { + Symphyocladia marchantioides } \\
\text { (Harvey) Falkenberg }\end{array}$ & no & Ardré et al. (1974) & Pacific Ocean \\
\hline \multicolumn{4}{|l|}{ Green seaweeds } \\
\hline - Bryopsis penicillata Suhr & yes & $\begin{array}{l}\text { A form of Bryopsis plumosa } \\
\text { acc. to Koster (1941) }\end{array}$ & Mediterranean \\
\hline $\begin{array}{l}\times \text { Cladophora michaelensis } \\
\text { Schmidt }\end{array}$ & yes & & \\
\hline $\begin{array}{l}\text { - Cladophora theotoni } \\
\text { Schmidt }\end{array}$ & yes & & Senegal \\
\hline $\begin{array}{l}\times \text { Cladophora weizenbauri } \\
\text { Schmidt }\end{array}$ & yes & & \\
\hline $\begin{array}{l}\text { - Codium elisabethae } \\
\text { Schmidt }\end{array}$ & yes & det. P. C. Silva & $\begin{array}{l}\text { Porto Santo } \\
\text { (Madeira arch.) }\end{array}$ \\
\hline
\end{tabular}

Table 8). In his comments he stressed the uncertain taxonomic position of these endemics. It is very probable that several of these are not separate taxa (Van den Hoek, pers. comm. for Cladophora) but as long as no new information is available they cannot be discarded. Detailed taxonomic research is needed as well for the relative (Atlantic) endemics, i.e. species that are restricted to one area (e.g. the Azores) in the Atlantic, but which occur also in other oceans (see also Tables 5 and 8).

\section{The Eurafrican coast}

The species of the Azorean seaweed floras are almost all shared by the Eurafrican mainland seaweed floras (Fig. 6). Most of these Azorean seaweeds occur on the Atlantic coasts as well as in the Mediterranean. Of most distribution groups large numbers of species are amphiatlantic, but in the warm-temperate distribution groups (Subtr-SCWT, Subtr.-NCWT, SCWT proper and SCWT-NCWT in Fig. 6 and WT in Table 6) not a single 
amphiatlantic species occurs. Thus a distinct E American imprint, so characteristic for the Cape Verdean seaweed flora (Prud'homme van Reine \& Van den Hoek, 1988) and possibly also present in Macaronesia s.s., is not present in the Azores.

In view of the relative geographic proximity of the Azores to the Eurafrican and Macaronesian coasts one would expect unimpeded seaweed dissemination between these coasts. This would result in seaweed floras being different as a result of differences in environmental regimes, particularly temperature regimes. However, the temperature regime of the Azores is similar to that of Madeira, and only slightly different from those of the oceanic Canary Islands (OC) and the warmer part of the Southern Cooler Warm Temperate area (Table 9). Nevertheless, dissimilarities between the Azorean seaweed

Table 9. Mean surface temperatures of the sea in ${ }^{\circ} \mathrm{C}$. For details see Prell et al. (1976), Crowley (1981), Sarnthein et al. (1982) and McIntyre \& Kipp (1976). For abbreviations of area designations see Table 1. LG = Last glaciation (ca 18000 years ago)

\begin{tabular}{|lccccccccccc|}
\hline \multicolumn{2}{|c}{ Area } & \multicolumn{2}{c}{ Subtr. Afr. } & \multicolumn{2}{c}{ AZ } & \multicolumn{2}{c}{ MAD } & \multicolumn{2}{c}{ OC } & \multicolumn{2}{c}{ SCWT } \\
Season & LG & Recent & LG & Recent & LG & Recent & LG & Recent & LG & Recent \\
\hline Summer & $19-24$ & $21-26$ & $18-20$ & $21-23$ & $22-23$ & $21.5-23$ & $19-22$ & $21.5-22.5$ & $12-19$ & $17.5-21.5$ \\
Winter & $12-17$ & $17.5-20.5$ & $12-15$ & $15-17.5$ & $14-16$ & $16-18$ & $12-14$ & $18-19.5$ & $4-12$ & $12.5-18$ \\
\hline
\end{tabular}

floras and these other seaweed floras are at the $50 \%$-level. Apparently other, nonenvironmental, possibly historical, factors are responsible for the separate and individual position of the Azorean seaweed floras. If this is true, the implication is that unimpeded seaweed dissemination between the Azores and other coasts is not possible.

\section{North America}

The absence of strictly warm temperate American species can be explained on the basis of differences in temperature regimes. The relationships between distribution boundaries and temperature responses of seaweeds have been experimentally determined for several species of the NE American tropical-to-temperate distribution group, the warm temperate Mediterranean-Atlantic distribution group, the amphiatlantic tropical-to-warm temperate distribution group and the amphiatlantic temperate distribution group (Yarish et al., 1984, 1986; see also Breeman, 1988). The warm temperate Mediterranean-Atlantic seaweeds have rather narrow growth and survival potentials at temperatures lower than $5^{\circ} \mathrm{C}$ or higher than $20^{\circ} \mathrm{C}$. These $\mathrm{E}$ Atlantic endemic species cannot grow along NE American shores, because the seasonal temperature range $\left(>20^{\circ} \mathrm{C}\right)$ at any point along the NE American coast exceeds their temperature ranges. This is most probably also the explanation of the absence of amphiatlantic strictly warm temperate seaweeds in the seaweed floras of the Azores.

The warm temperate NE American coast algae, however, need high seawater temperatures in summer for growth and reproduction. These high seawater temperatures do not occur in the Azores and thus the few warm-temperate American seaweeds that have also been recorded from E Atlantic coasts cannot grow at the Azorean coasts. 
Table 10. Species of Azorean seaweeds that may have become extinct during the last glaciation. $1=$ also in warm temperate America; $2=$ also in the western part of the Mediterranean; $3=$ also recorded from outside the $\mathrm{N}$ and central Atlantic

\begin{tabular}{|c|c|}
\hline Amphiatlantic species & \\
\hline \multicolumn{2}{|l|}{ Red algae } \\
\hline Amphiroa fragilissima (L.) Lamour. & 1.2 \\
\hline \multicolumn{2}{|l|}{$\begin{array}{l}\text { Ampniroa tragminssma (L.) Lamour. } \\
\text { Audouinella barbadensis (Vick.) Woelk. }\end{array}$} \\
\hline Heterosiphonia crispellata (C. Ag.) Wynne & 2 \\
\hline Jania adhaerens Lamour. & 1.2 \\
\hline Platoma cyclocolpa (Mont.) Schmitz & 2 \\
\hline Polysiphonia havanensis Mont. & 1 \\
\hline Porolithon onkodes (Heydr.) Fosl. & 3 \\
\hline \multicolumn{2}{|l|}{ Brown algae } \\
\hline Dictyota adnata Zanard. & 3 \\
\hline Dictyota menstrualis (Hoyt) Schnet. et al. & 1 \\
\hline Lobophora variegata (Lamour.) Wom. & 1.2 .3 \\
\hline \multicolumn{2}{|l|}{ Sargassum cymosum C. Ag. } \\
\hline \multirow{2}{*}{\multicolumn{2}{|c|}{$\begin{array}{l}\text { Sargassum desfontainesii (Turn.) C. Ag. } \\
\text { Spatoglossum schroederi (Mert.) Kütz. }\end{array}$}} \\
\hline & \\
\hline Green algae & \\
\hline \multirow{2}{*}{\multicolumn{2}{|c|}{ Chaetomorpha pachynema Mont. }} \\
\hline & \\
\hline Derbesia furcellata (Zanard.) Ardiss. & 2 \\
\hline Rhizoclonium ambiguum (Hook. \& Harv.) Kütz & Struvea anastomosans (Harv.) Picc. \\
\hline \multirow{2}{*}{\multicolumn{2}{|c|}{ East Atlantic species }} \\
\hline & \\
\hline \multicolumn{2}{|l|}{ Red algae } \\
\hline Griffithsia phyllamphora J. Ag. & 2 \\
\hline Halichrysis depressa (Mont.) Born. & 2 \\
\hline Jania crassa Lamour. & 3 \\
\hline Lithothamnion philipii Fosl. & 2 \\
\hline Neogoniolithon orotavicum (Fosl.) Lemoine & \\
\hline Peyssonnelia rosa-marina Boud. \& Deniz. & 2 \\
\hline Polysiphonia sertularioides (Grat.) J. Ag. & 2 \\
\hline Pseudolithophyllum esperi Lemoine & \\
\hline \multicolumn{2}{|l|}{ Brown algae } \\
\hline \multicolumn{2}{|l|}{ Cystoseira abies-marina (Gmel.) C. Ag. } \\
\hline \multicolumn{2}{|l|}{$\begin{array}{l}\text { Green algae } \\
\quad \text { Cladophora theotonii Schmidt }\end{array}$} \\
\hline \multicolumn{2}{|l|}{ Macaronesian species } \\
\hline \multicolumn{2}{|l|}{$\begin{array}{l}\text { Red algae } \\
\quad \text { Gelidium canariense (Grun.) Seoane-C. }\end{array}$} \\
\hline \multicolumn{2}{|l|}{ Brown algae } \\
\hline Dictyota liturata J. Ag. & 3 \\
\hline $\begin{array}{l}\text { Green algae } \\
\quad \text { Codium elisabethae Schmidt }\end{array}$ & \\
\hline
\end{tabular}


On the other hand, several species of seaweeds which are confined to the tropics in America can also be found on Azorean coasts (Table 10). In that table all amphiatlantic seaweeds not recorded for Warm Temperate America are examples of the phenomenon. Upon the assumption that the Caribbean and Azorean populations of one and the same species have the same temperature response (an assumption that has to be tested first), it can be supposed that these algae meet at the Warm Temperate American coast with conditions which do not permit their survival. These conditions are possibly an adverse combination of temperature, light and/or photoperiod (Van den Hoek, pers. comm.). This combination of conditions evidently does not occur in at least parts of the Azorean (and other warm E Atlantic) coasts and thus a detailed study of these conditions as well as of the tolerances of the seaweeds occurring there can possibly elucidate this distributional difference.

\section{Cold spells}

For a number of Azorean seaweeds the last glacial period and probably also earlier cold periods in Pliocene and Pleistocene could have been crucial. During the last glacial period (ca 18000 years ago) surface temperatures of the seawater around the Azores were a few degrees centigrade lower than nowadays (Table 9). This table shows that mean surface temperatures of the sea around the Azores are within the values given for recent mean surface temperatures in the Southern Cooler Warm Temperate subregion (= SCWT): Azorean seawater temperatures during the last glaciation were near the lowest temperatures of recent SCWT seawater, while recent Azorean seawater temperatures are, especially in summer, just a few degrees higher than recent SCWT seawater. On the basis of the results of Yarish et al. $(1984,1986)$, it is clear that these slight differences in seawater temperatures may have been sufficient for some warm temperate and tropicalto-warm temperate species to pass the lethal northern boundary. This means that only those seaweeds that nowadays occur in the warmer parts of SCWT as well as on the Azores may have suffered from the lower seawater temperatures occurring during the last glaciation. Only these algae can therefore be expected to have become extinct during that cold period, while all other seaweeds could have survived that period. Of the 44 recorded species of which the distribution type is Tropical-to-SCWT, Subtropical-toSCWT or strictly SCWT (endemics excluded) the 33 species not recorded from European coasts (summer isotherms below $21^{\circ} \mathrm{C}$, winter isotherms below $15^{\circ} \mathrm{C}$ ) may have become extinct according to the above assumptions (see Table 10). Several of these species, however, occur in the western part of the Mediterranean or along the Warm Temperate American coasts and thus can survive lower winter temperatures.

Furthermore, the hypothesis that strictly tropical species are restricted to the tropics on the basis of their temperature responses has been tested for three strictly tropical species (Prud'homme van Reine \& Van den Hoek, 1988). The tests demonstrated that these tropical seaweeds are potentially capable of surviving much lower temperatures than those occurring in the area where these seaweeds can be found nowadays. This may also be the case for some of these Azorean warm water seaweeds.

If, however, the supposed extinction took place during the last glacial maximum, these species, then extinct, must have reached the islands later and thus within the last 18000 years. Thus, most of the seaweeds now occurring in the Azores might have taken 1-5 million years to reach this archipelago, but the seaweeds that need higher seawater 
temperatures must have reached the Azores within the relatively short period of 18000 years. For the Cape Verde Islands (Prud'homme van Reine \& Van den Hoek, 1988) and for the archipelagos of Macaronesia s.s., a different origin could be suggested for several of the warm-water species as opposed to species from colder waters, but for Azorean seaweeds this is not possible. They could have come from African coasts, from American coasts or from other Macaronesian islands. These suggestions, however, do not differ from suggestions based on recent distribution and recent routes of transport as discussed above. Of the 33 species discussed above (see Table 10), a total of 19 species are of amphiatlantic occurrence and 13 are E Atlantic endemics.

\section{Alternative theories}

For a number of species of the Cape Verde Islands it could be suggested, as an alternative theory, that they represent remnants of a formerly continuous Tethyan seaweed flora (Prud'homme van Reine \& Van den Hoek, 1988). A suggestion like this can be tested by using the methods of vicariance biogeography (see Garbary, 1987). The Azores emerged less than 5 million years ago (Schmincke, 1982), although the oldest submarine parts probably originated in the early Miocene (Mitchell-Thomé, 1976). Thus, the Azores emerged much later than the closure of Tethys and Paratethys and no survivors of an original Tethyan tropical early miocene seaweed flora can be suggested for the Azorean seaweed floras.

\section{CONCLUSIONS}

The number of species of seaweeds found in the Azores is low compared to other Macaronesian archipelagos and is even smaller than the number of species recorded from the tiny Salvage Islands (Table 5). Reasons for this paucity may be the well-known extinction rule for island biota, especially for islands which are located at considerable distance from other shores (see Mac Arthur \& Wilson, 1967).

The long migration route for seaweeds from the American coasts to the Azores as well as from the Eurafrican and Macaronesian coasts to the Azores, and the small dimensions of the islands and thus of the length of their coasts are possible reasons for the paucity of the assembled seaweed flora of the Azores. The seaweeds of the Azores can therefore be characterized as chance survivors of chance invasions by long-range dispersal (see Van den Hoek, 1987).

Acknowledgements. I wish to express my cordial thanks to all the persons who helped me name the seaweeds collected during the CANCAP-expeditions. I am also much indebted to Dr. J. van der Land, Chief scientist of these CANCAP-expeditions, and to officers and crew of the oceanographic research vessel of the Dutch Royal Navy, Hr. Ms. Tydeman, for their hospitality and help during the expeditions. Many of the ideas elaborated in this paper were acquired during stimulating discussions with Prof. Dr. C. van den Hoek. My acknowledgements are especially due to M.S.M. Sosef and G.D.E. Povel for their help in selecting, preparing and using computer software, to $H$. Pakker who did most of the preliminary work, and to J. H. van Os and J. M. de Wolf for technical help in preparation of the paper. 


\section{LITERATURE CITED}

Afonso-Carrillo, J., 1984. Estudios en las algas Corallinaceae (Rhodophyta) de las Islas Canarias. II. Notas taxonomicas. - Vieraea 13, 127-144.

Afonso-Carrillo, J. \& Gil-Rodríguez, M. C., 1980. Datos para la flora marina de la Isla de Fuerteventura. - Vieraea 10, 147-170.

Afonso-Carrillo, J. \& Gil-Rodríguez, M. C., 1982. Sobre la presencia de un fondo de "maerl" en las Isias Canarias. - Collnea bot. $13(2), 703-708$.

Afonso-Carrillo, J., Gil-Rodríguez, M. C., Haroun Tabraue, R., Villena Balsa, M. \& Wildpret de la Torre, W., 1984. Adiciones y correcciones al catálogo de algas marinas bentonicas para el Archipiélago Canario. - Vieraea, 13, 27-49.

Afonso-Carrillo, J., Gil-Rodríguez, M. C., Tabraue, R. H. \& Wildpret de la Torre, W., 1985. Algunos aspectos de la aplicación de la microscopia electronica de barrido al estudio de las algas Corallinaceae (Rhodophyta). - Cah. Biol. mar. 25, 427-433.

Ardré, F., Boudouresque, C. F. \& Cabioch, J., 1973. Note préliminaire sur la mission "Biaçores" du N. O. Jean Charcot (Algologie). - Bull. Soc. phycol. Fr. 18, 30-32.

Ardré, F., Boudouresque, C. F. \& Cabioch, J., 1974. Symphyocladia marchantioides (Harvey) Falkenberg (Rhodomélacées, Céramiales) aux Açores. - Bull. Soc. phycol. Fri 19, 178-182.

Askenasy, E., 1896. Enumération des algues des îles du Cap Vert. - Bolm Soc. broteriana 13, $150-175$.

Audiffred, P. A. J., 1985. Marine algae of El Hierro (Canary Islands). - Vieraea, 14, 157-183.

Audiffred, P. A. J. \& Prud'homme van Reine, W. F., 1985. Marine algae of llha do Porto Santo and Deserta Grande (Madeira Archipelagao). - Bolm Mus. munic. Funchal 37, 20-51.

Audiffred, P. A. J. \& Weisscher, F. L. M., 1984. Marine algae of Selvagem Grande (Salvage Islands, Macaronesia). - Bolm Mus. munic. Funchal 36, 5-37.

Bailey, J. W. \& Harvey, W. H., 1862. Algae. In: United States Exploring Expedition during the years 1838-1842 under the command of Charles Wilkes. 17 (Botany 1), 153-192, Pl. 1-9 (preprint).

Bodard, M. \& Mollion, J., 1974. La végétation infralittorale de la petite côte sénégalaise. - Bull. Soc. phycol. Fr. 19, 193-221.

Bornet, E., 1892. Les algues de P.-K.-A. Schousboe, récoltées au Maroc et dans la Méditerranée de 1815 à 1829. - Mém. Soc. natn. Sci. nat. math. Cherbourg'28, 165-376.

Boudouresque, C. F. \& Perret, M., 1977. Inventaire de la flore marine de Corse (Méditerranée). Cramer, Vaduz, $171 \mathrm{pp}$.

Boudouresque, C. F., Perret-Boudouresque, M. \& Knoepffler-Peguy, M., 1984، Inventaire des algues marines benthiques dans les Pyrénées Orientales (Méditerranée, France). - Vie Milieu (Sér. A) $34(1), 41-59$.

Breeman, A. M., 1988. Relative importance of temperature and other factors in determining geographic boundaries of seaweeds: experimental and phenological evidence. - Helgoländer Meeresunters. 42, 199-241.

Cabioch, J., 1974. Un fond de Maerl de l'Archipel de Madère et son peuplement végétal. - Bull. Soc. phycol. Fr. 19, 74-82.

Codomier, L., 1971. Recherches sur les Kallymenia (Cryptonemiales, Kallymeniacées). 1. Les espèces méditerranéennes. - Vie Milieu (Sér. A) 22 (1), 1-54.

Collins, F. S. \& Hervey, A. B., 1917. The algae of Bermuda. - Proc. Am. Acad. Arts Sci, 53, 1-195.

Coppejans, E., 1977. Bijdrage tot de studie van de wierpopulaties (Chlorophyceae, Phaeophyceae, Rhodophyceae) van het fotofiel infralittoraal in het noord-westelijk Mediterraan Bekken. Diss., Univ. Ghent, 601 pp., $296 \mathrm{pl}$.

Coppejans, E., 1979. Végétation marine de la Corse (Méditerranée). III. Documents pour la flore des algues. - Botanica mar. 22, 257-266.

Coppejans, E., 1983. Iconographie d'algues méditerranéennes. Cramer, Vaduz, 28 pp., 296 pl.

Coppejans, E. \& Boudouresque, C. F., 1983. Végétation marine de la Corse (Mêditerranée). VI. Documents pour la flore des algues. - Botanica mar. 26, 457-470.

Crowley, T. J., 1981. Temperature and circulation changes in the eastern North Atlantic during the last 150,000 years: evidence from the planktonic foraminiferal record. - Mar. Micropaleontol. 6 , 97-129.

Dangeard, P., 1949. Les algues marines de la côte occidentale du Maroc. - Botaniste 34, 89-189. 
Dangeard، P.، 1952. Algues de la presqu', île du Cap Vert (Dakar) et de ses environs. - Botaniste 36, 193-331.

Debray, F., 1897. Catalogue des algues du Maroc, d'Algérie et de Tunisie. Librairie Adolphe Jourdan, Algiers, $77 \mathrm{pp}$.

Denizot, M., 1968. Les algues Floridées encroutantes (à l'exclusion des Corallinacées). Laboratoire de Cryptogamie. Muséum natn. Hist. nat., Paris, 310 pp.

Falkenberg, P., 1901. Die Rhodomelaceen des Golfes von Neapel. In: Flora und Fauna des Golfes von Neapel 26, 1-754.

Feldmann, J., 1935. Algues marines des îles du Cap Vert récoltées par M. le professeur Aug. Chevalier. - Revue Bot. appl. Agric. trop. 11 (2), 1069-1071.

Feldmann, J., 1946. La flore marine des îles atlantides. - Mém. Soc. Biogéogr. 28, 395-435.

Feldmann-Mazoyer, G., 1940. Recherches sur les Céramiacées de la Méditerranée. Imprimerie Minerva, Algiers, $510 \mathrm{pp}$.

Funk, $G$, , 1927. Die Algenvegetation des Golfs von Neapel. - Pubbl. Staz. Zool, Napoli, 7, 1-507.

Funk, G., 1955. Beiträge zur Kenntnis der Meeresalgen von Neapel, zugleich mikro-photographischer Atlas. - Pubbl. Staz. Zool. Napoli 25, 1-178.

Furnari, G. \& Scammacca, B., 1973. Ricerche floristiche sulle alghe marine della Sicilia orientale. Nuovo contributo. - Boll. Sed. Accad. gioenia Sci. nat. (Ser. 4) $11(7,8), 1-22$.

Gallardo, T., Gómez Garreta, A., Ribera, M. A., Alvarez, M. \& Conde, F., 1985. A preliminary checklist of Iberian benthic marine algae. Real Jardín Botánico, Madrid, 83 pp.

Garbary, D., 1987. A critique of traditional approaches to seaweed distribution in light of the development of vicariance biogeography. - Helgoländer Meeresunters. 41, 235-244.

Gayral, P., 1958. Algues de la côte atlantique marocaine. (La nature au Maroc 2.) Rabat, 523 pp.

Gayral, P., 1960. Sur la présence au Maroc et à Dakar de Levringia brasiliensis (Mont.) B. Joly. Revue algol. 5, 49-54.

Gayral, P., 1961. Liste commentée des algues marines nouvelles pour le Maroc, reconnues depuis 1949. - Bull. Soc. Sci. nat. phys. Maroc, 41, 1-18.

Giaccone, G., 1969. Raccolte di Fitobenthos sulla banchina continentale italiana. - G. Bot. ital. 103, $485-514$.

Gil-Rodriguez, M. C. \& Afonso-Carrillo, J., 1980. Catálogo de las algas marinas bentonicas (Cyanophyta, Chlorophyta, Phaeophyta y Rhodophyta) para el archipiélago Canario. Aula de Cultura de Tenerife, $65 \mathrm{pp}$.

Gil-Rodríguez, M. C. \& Afonso-Carrillo, J., 1982. Sobre la distribución de la familia Dasycladaceae (Chlorophyta) en las islas Canarias. - Collnea bot. 13 (2), 831-839.

Gil-Rodríguez, M. C., Afonso-Carrillo, J., Haroun-Tabraue, R. \& Wildpret de la Torre, W., 1984. Iniciación al estudio taxonómico-ecológico del género Sargassum C. Agardh (Phaeophyta) en las islas Canarias. - Act. 4. Simposio Iberico Est. Benthos Mar. 3, 83-92.

Gil-Rodríguez, M. C., Afonso-Carrillo, J., Haroun-Tabraue, R. \& Wildpret de la Torre, W., 1985. Adiciones al catálogo de algas marinas bentonicas para el Archipiélago Canario. II. - Vieraea 15, 101-112.

Hamel, G., 1924-1931. Chlorophycées de France. - Reprint. from Revue algol.

Hamel, G., 1924-1936. Floridées de France. - Reprint. from Revue algol.

Hamel, G., 1931-1939. Phéophycées de France. 432 pp.

Hamel, G. \& Lemoine, P., 1952. Corallinacées de France et d'Afrique du Nord. - Archs Mus. natn. Hist. nat., Paris 7 (1), 1-136.

Hariot, P., 1911. Algues de Mauritanie recueillies par M. Chudeau. - Bull. Soc. bot. Fr. 58, 438-445.

Haroun Tabraue, R. J., Gil-Rodríguez, M. C., Afonso-Carrillo, J. \& Wildpret de la Torre, W., 1984. Estudio ecológico y fenelógico de algunas especies del género Caulerpa Lamouroux presentes en el Archipiélago Canario. - Act. 4. Simposio Iberico Est. Benthos Mar. 3, 75-82.

Hoek, C. van den, 1963. Revision of the European species of Cladophora. Brill, Leiden, 248 pp.

Hoek, C. van den, 1979. The phytogeography of Cladophora (Chlorophyceae) in the northern Atlantic Ocean, in comparison to that of other benthic algal species. - Helgoländer wiss. Meeresunters. 32, 374-393.

Hoek, C. van den, 1982a. A taxonomic revision of the American species of Cladophora (Chlorophyceae) in the North Atlantic Ocean and their geographic distribution. - Verh. K. ned. Akad. Wet. (Afd. Natuurk., 2. R.) 78, 1-236. 
Hoek, C. van den, $1982 \mathrm{~b}$. The distribution of benthic marine algae in relation to the temperature regulation of their life histories. - Biol. J. Linn. Soc. 18, 81-144.

Hoek, C. van den, 1982c. Phytogeographic.distribution groups of benthic marine algae in the North Atlantic Ocean. A review of experimental evidence from life history studies. - Helgoländer Meeresunters. 35, 153-214.

Hoek, C. van den, 1984. World-wide latitudinal and longitudinal seaweed distribution patterns and their possible causes, as illustrated by the distribution of Rhodophytan genera. - Helgoländer Meeresunters. 38, 227-257

Hoek, C. van den, 1987. The possible significance of long-range dispersal for the biogeography of seaweeds. - Helgoländer Meeresunters. 41, 261-272.

John, D. M., Price, J. H., Maggs, C. A. \& Lawson, G. W., 1979. Seaweeds of the western coast of tropical Africa and adjacent islands: a critical assessment. III. Rhodophyta (Bangiophyceae). Bull. Br. Mus. nat. Hist. (Bot.) 7 (2), 69-82.

Koster, J. T., 1941. Quelques observations sur les Bryopsis du Golfe de Naples. - Blumea 4, 225-258.

Kuckuck, P. 1964. Ectocarpaceen-Studien. Biologische Anstalt Helgoland, Hamburg, 239 pp.

Lauret, M., 1968. Morphologie, phénologie, répartition des Polysiphonia marins du littoral Languedocien. I, section Oligosiphonia. - Naturalia monspel. 18, 347-373.

Lauret, M., 1970. Morphologie, phénologie, répartition des Polysiphonia marins du littoral Languedocien. II, section Polysiphonia. - Naturalia monspel. 21, 121-163.

Lawson, G. W. \& John, D. M., 1977. The marine flora of the Cap Blanc peninsula: its distribution and affinities. - Bot. J. Linn. Soc. 75, 99-118.

Lawson, G. W. \& John, D. M., 1982. The marine algae and coastal environment of Tropical West Africa. - Nova Hedwigia (Beih.) 70, 1-445.

Lawson, G. W. \& Price, J. H., 1969. Seaweeds of the western coast of tropical Africa and adjacent islands: a critical assessment. I. Chlorophyta and Xanthophyta. - Bot. J. Linn. Soc. 62, 279-346.

Lemoine, P., 1964. Contribution a l'étude des Mélobésiées de l'Archipel du Cap Vert. - Proc. int. Seaweed Symp., 4, 234-239.

Levring, T., 1974. The marine algae of the Archipelago of Madeira. - Bolm Mus. munic. Funchal 28, 5-111.

MacArthur, R. H. \& Wilson, E. O., 1967. The theory of island,biogeography. Princeton Univ. Press, Princeton, $203 \mathrm{pp}$.

McIntyre, A. \& Kipp, N. G., 1976. Glacial North Atlantic 18,000 years ago: a CLIMAP reconstruction. - Mem. Geol. Soc. Am. 145, 43-76.

Meñez, E. G. \& Mathieson, A. C., 1981. The marine algae of Tunisia. - Smithson. Contr. mar. Sci. 10, 1-59.

Mitchell-Thomé, R. C., 1976. Geology of the middle atlantic islands. Borntraeger, Berlin, $382 \mathrm{pp}$.

Naegelé, A., 1960. Note sur le peuplement algal de la presqu'île du Cap Vert. - Notes afr. 88, 118-119.

Ollivier, G., 1929. Etude de la flore marine de la Côte d'Azur. - Annls Inst, océanogr. Monaco 7, 53-173.

Pedersen, P. M., 1983. Notes on marine, benthic algae from Madeira in nature and in culture. Bocagiana $70,1-8$.

Preda, A., 1908. Florideae. In: Flora italica cryptogama 2: Algae 1 (2), 1-462.

Prell, W. L., Gardner, J. V., Bé, A. W. H. \& Hays, J. D., 1976. Equatorial Atlantic and Caribbean foraminiferal assemblages, temperatures, and circulation: interglacial and glacial comparisons. Mem. geol. Soc. Am. 145, 247-266.

Price, J. H., John, D. M. \& Lawson, G. W., 1978. Seaweeds of the western coast of tropical Africa and adjacent islands: a critical assessment. II: Phaeophyta. - Bull: Br. Mus. nat. Hist. (Bot.) 6, 87-182.

Price, J. H., John, D. M. \& Lawson, G. W., 1986. Seaweeds of the western coast of tropical African and adjacent islands: a critical assessment. IV: Rhodophyta (Florideae), 1. Genera A-F. - Bull. Br. Mus. nat. Hist. (Bot.) 15 (1), 1-122.

Primo, C., 1953. A contribution to the study of the seaweeds of Spanish West Sahara. - Proc. int. Seaweed Symp. 1, 23-24.

Prud'homme van Reine, W. F., 1982. A taxonomic revision of the European Sphacelariaceae (Sphacelariales, Phaeophyceae). Brill, Leiden, $294 \mathrm{pp}$.

Prud'homme van Reine, W. F., 1984. Neomeris in the Cape Verde Islands, a new record for the 
eastern coast of the Atlantic Ocean (Dasycladales, Chlorophyceae). - Cour. Forsch.-Inst. Senckenberg, 68, 139-142.

Prud'homme van Reine, W. F., Gil-Rodríguez, M. C., Haroun Tabraue, R. J., Afonso-Carrillo, J. \& Wildpret de la Torre, W., 1984. Polyphysa parvula (Solms-Laubach) Schnetter \& Bula Meyer (Dasycladaceae, Chlorophyta) en la région Macaronesia. - Vieraea 13, 219-224.

Prud'homme van Reine, W. F. \& Hoek, C. van den, 1988. Biogeography of Cape Verdean seaweeds.Cour. Forsch.-Inst. Senckenberg 104 (in press).

Pryor, J., 1967. Marine biological report. - Final report of the Chelsea College Azores Expedition, July-October 1965, 17-30.

Reinbold, T., 1908. Die Meeresalgen der Deutschen Südpolar-Expedition 1901-1903. Ergebn. dt. Südpolar-Exped. 1901-1903 (Botanik) 8, 279-202.

Sarnthein, M., Thiede, J., Pflaumann, U., Erlenkeuser, H., Fütterer, D., Koopmann, B., Lange, H. \& Seibold, E., 1982. Atmospheric and oceanic circulation patterns off Northwest Africa during the past 25 million years. In: Geology of the Northwest African continental margin. Ed. by U. von Rad, K. Hinz, M. Sarnthein \& E. Seibold. Springer, Berlin, 545-604.

Sauvageau, C., 1912. A propos des Cystoseira de Banyuls et de Guéthary. - Bull. Stn biol. Arcachon $14,133-556$.

Schmidt, O. C., 1931. Die marine Vegetation der Azoren in ihren Grundzügen dargestellt. - Biblthca bot. $102,1-116$.

Schmincke, H. U., 1982. Volcanic and chemical evolution of the Canary Islands. In: Geology of the Northwest African continental margin. Ed. by U. von Rad, K. Hinz, M. Sarnthein \& E. Seibold. Springer, Berlin, 273-306.

Schotter, G., 1968. Recherches sur les Phyllophoracées. - Bull. Inst. océanogr. Monaco 67, 1-99.

Seoane-Camba, J., 1960. Nota sobre algunas especies de Algas de la costa occidental africana (sur de Cabo Blanco). - Investigacion pesq. 16, 91-103.

Silva, P. C., 1960. Codium (Chlorophyta) of the tropical Western Atlantic. - Nova Hedwigia 21, 497-536.

Sourie, R., 1954a. Principaux types de zonations verticales des algues sur le littoral rocheux de la presqu' île du Cap Vert (zone intercotidale). - Rapp. Commn 8me Congr. int. Bot. 17, 151-153.

Sourie, R., 1954b. Contribution à l'étude des côtes rocheuses du Șénégal. - Mém. Inst. fr. Afr. noire $38,1-342$.

South, G. R. \& Tittley, I., 1986. A checklist and distributional index of the benthic marine algae of the North Atlantic Ocean. British Museum (Natural History), London, 76 pp.

Taylor, W. F., 1957. Marine algae of the northeastern coast of North America. - Univ. Mich. Stud. Scient. Ser. 13, 1-509.

Taylor, W. F., 1960. Marine algae of the eastern tropical and subtropical coasts of the Americas. Univ. Mich. Press, Ann Arbor, $870 \mathrm{pp}$.

Verlaque, M., 1981. Contribution à la flore des algues marines de Méditerranée. Espèces nouvelles pour la Méditerranée occidentale. - Botanica mar. 24, 559-568.

Verlaque, M. \& Boudouresque, C.-F., 1981. Végétation marine de la Corse (Méditerranée). V. Documents pour la flore des algues. - Revue Biol. Ecol. Médit. 8, 139-156.

Verlaque, M., Boudouresque, C.-F., Meinesz, A., Giraud, G. \& Marcot-Coqueugniot, J., 1977. Végétation marine de la Corse (Méditerranée). II. Documents pour la flore des algues. - Vie Milieu (Ser. A) 27, 437-456.

Verlaque, M. \& Tine, J., 1981. Marine vegetation of Toulon (Var, France): Algues and seagrasses. Thalassographica 4, 5-38.

Wynne, M. J., 1986. A checklist of benthic marine algae of the tropical and subtropical western Atlantic. - Can. J. Bot. 64, 2239-2281.

Yarish, C., Breeman, A. M. \& van den Hoek, C., 1984. Temperature, light, and photoperiod responses of some Northeast American and West European endemic rhodophytes in relation to their geographic distribution. - Helgoländer Meeresunters. 38, 273-304.

Yarish, C., Breeman, A. M. \& van den Hoek, C., 1986. Survival strategies and temperature responses of seaweeds belonging to different biogeographic distribution groups. - Botanica mar. 29, 215-230. 